\title{
RECENZJE I OMÓWIENIA
}

\author{
KLIO. Czasopismo poświęcone dziejom Polski i powszechnym
}

PL ISSN 1643-8191, t. 21 (2) 2012, s. 197-246

\section{Bogusława Jodłowska, Pedagogika sokratejska, Oficyna Wydawnicza „Impuls”, Kraków 2012, ss. 294}

$\mathrm{K}$

siążka Bogusławy Jodłowskiej Pedagogika sokratejska to publikacja, która na pierwszy rzut oka robi dobre wrażenie. Obiecujący tytuł, poważny (bliprojektowana okładka - wszystkie te elementy zachęcają do jej zakupu i czynią nadzieję na intelektualną ucztę, tym bardziej że sama postać Sokratesa, mimo upływu prawie dwu i pół tysiąca lat od jego śmierci, wciąż pozostaje historyczną zagadką. Wszystko, co o nim wiemy, pochodzi głównie od jego uczniów, Platona i w mniejszym stopniu - Ksenofonta. Jedynym źródłem z okresu życia Sokratesa jest komedia Arystofanesa Chmury, w której ateński filozof przedstawiony został jednak w krzywym zwierciadle. Sam myśliciel zaś - jak wiemy - nie pozostawił po sobie żadnych pism.

Zasiadając zatem do lektury książki Jodłowskiej, miałem nadzieję dowiedzieć się czegoś nowego (nie w sensie ustaleń faktograficzno-biograficznych, rzecz jasna, ale w sensie - jeżeli nie nowatorskiej, to przynajmniej ciekawej - interpretacji myśli Sokratesa). Nadzieja była tym większa, że tytuł zapowiadał odczytanie Sokratesa z perspektywy nie filozofii, tylko pedagogiki. Intrygowało mnie to tym bardziej, że: po pierwsze - lubię ujęcia interdyscyplinarne, a po drugie - przez wiele lat uczyłem w szkole i często stosowałem wywodzącą się od Sokratesa metodę heurezy.

Już po przeczytaniu kilku stron pojawił się pierwszy niepokój i nasunęły się pytania, jaki jest właściwie charakter tej książki (sądziłem, że naukowy - oznaką tego były liczne przypisy i w miarę obszerna bibliografia) i - przede wszystkim dla kogo została ona napisana (byłem przekonany, że dla czytelnika raczej wykształconego - świadczyły o tym kategorie pojęciowe zawarte w spisie treści, np. „sokratejska antropologia pedagogiczna”, „metodologia procesu wychowania”, „teoria koherencji wiedzy”, „ontologiczna koncepcja sokratejskiego dialogu” itp.). Po przeczytaniu pierwszej z trzech części, zatytułowanej Człowiek i Logos. $Z$ podstaw sokratejskiej antropologii pedagogicznej, miałem w zasadzie już dość. Ileż razy można 
powtarzać tę samą, w gruncie rzeczy banalną tezę, że tak jak Sokrates uczył Ateńczyków prawdziwej mądrości, tak „warto współcześnie ponawiać pytanie o sokratejską mądrość wychowawczą i próbować ją pojąć na nowo" (s. 108). Autorka zamiast rzeczowej analizy problemu bezustannie jak zaklęcie powtarza co parę stron te same słowa, ciągle wraca do tych samych myśli, a w niektórych miejscach przepisuje wręcz te same partie tekstu, które wcześniej zostały już przedstawione. Wszystko to powoduje, że Czytelnik z dużymi oporami sięga do drugiej części pracy zatytułowanej Logos jako Dialogos. Pedagogika sokratejska - metodologia procesu wychowania. I niestety nic się nie zmienia, a właściwie jest jeszcze gorzej. Trudno nie być poirytowanym, kiedy czyta się takie np. zdania: „Człowiek mądry jakością życia zaświadcza o swoich przekonaniach i tym właśnie różni się od innych, którzy co innego mówią, a co innego robią. Przykładem człowieka, którego słowa szły w parze z czynami, może być właśnie Sokrates, przedstawiający się jako ten, który "nic nie wie", ale w odróżnieniu od innych, mający tego stanu wyraźną świadomość, niepozwalającą na arogancję i bezmyślne przeżywanie życia. [...] W antyku każdy uczący się musiał wejść na drogę dążenia do mądrości, co znaczyło przemianę duchową, wypływającą z poznającego "pielgrzymowania". W starożytności edukacja łączyła się z "uprawą umysłu" pod okiem starszego, bardziej doświadczonego, a przede wszystkim mądrego nauczyciela. Przykładem takiej postaci może być centaur Chiron (sic!), który wychował wielu herosów [...]” (s. 130); „Sokrates poświęcił życie wychowaniu swoich uczniów, a sensem tego wychowania miał być człowiek mądry i dobry, bo tylko taki mógł żyć życiem wartościowym, godnym człowieka. [...] Sokrates poświęcił się swoim uczniom bezgranicznie i robił to bezinteresownie, w imię miłości, którą do nich żywił. Widać tu podobieństwo do ks. Jana Bosko [...]”. (s. 145-146); „Sokrates bardzo lubił myślenie, było ono jego pasją. Myślał powoli i z wielką starannością analizował pojęcia, bo rzeczywiste myślenie jest tam, gdzie są jasne pojęcia, będące wobec siebie w harmonii” (s. 163).

Oszczędzę Czytelnikowi dalszych przykładów narracji Jodłowskiej, która bliższa jest stylowi szkolnego wypracowania przeciętnego ucznia gimnazjum niż stylowi naukowej książki. I przyznam szczerze, że gdybym nie wyznaczył sobie zadania napisania recenzji z tej pracy, na pewno nie sięgnąłbym do ostatniej jej części, zatytułowanej „Plus ratio quam vis”. Pedagogika sokratejska w XXI wieku. Tytułowa sentencja (tłumaczona przez autorkę: „Niech rozum, mądrość zamiast siły rządzą”) to dewiza Uniwersytetu Jagiellońskiego, w którym Jodłowska przez wiele lat pracowała. Autorka zwraca się zresztą wprost do swojej Alma Mater, aby stała się ona uniwersytetem sokratejskim, opartym na wartościach prawdy i dobra. Jest bowiem zdania, że rzeczywistość jest zgoła inna. Wielokrotnie stwierdza, że żyjemy w „trudnych czasach”, a raz nawet używa określenia: „Polska "czasów mrocznych”” (s. 236). Ostrzega, że „prymat obrazu (tego, co widzialne) nad słowem (tego, co zrozumiałe) 
może doprowadzić do zatracenia umiejętności myślenia, gdyż opiera się na bezrozumnym patrzeniu” (s. 250). Ubolewa, że współcześnie próbuje się „,budować świat bez wartości prawdy", świat, w którym do wychowania młodzieży potrzebny jest częściej „uniwersytet sofistyczny, a nie sokratejski” (s. 230).

Jodłowska w ogóle nie rozumie demokratycznej, a więc pluralistycznej z założenia, rzeczywistości. Boi się mediów i kultury masowej, które „kształtują umysły na jedną modłę” (s. 249). Komputer rozumie jako narzędzie, które opiera się „na obrazach rzeczy wyimaginowanych” (sic!). Chciałaby oprzeć całą pedagogikę (i dydaktykę) na naukach Sokratesa, nie zważając, że Sokrates nie nauczał dzieci (nawet własnych!), tylko osoby dorosłe. W jaki sposób autorka wyobraża sobie wydobywanie „prawdy” z umysłu np. siedmiolatka? Jak w takim przypadku burzyć za pomocą elenktyki coś, co jeszcze nie zostało zbudowane? Jak odpowiedzieć małemu dziecku na zadane przez nie „naiwne” pytanie: dlaczego Sokrates nie interesował się własną rodziną, skazując ją na biedę? Chyba nie tak, jak proponuje autorka: [Sokrates] „Uważał, że jego najważniejszym zadaniem jest ratowanie młodych ludzi przed deprawacją sofistów, którzy nie dbali o mądrość, prawdę i dobro, ale o władzę i technikę przekonywania do swoich czynów, które ukierunkowane były na zdobywanie władzy w państwie. W imię tego zadania wychodził z domu, zostawiając dzieci i żonę, i spotykał się z uczniami, by pokazać im inne wartość niż te, których nauczali sofiści” (s. 145-146).

Pedagogika sokratejska to książka, która nie powinna się była ukazać, a na pewno nie powinna stroić się w szaty książki naukowej. Może ona aspirować co najwyżej do miana pracy publicystycznej i to o marnych zresztą walorach. Jodłowska przez cały czas zestawia „złych” sofistów z „dobrym” Sokratesem. Ten kontrast ma nie tylko uwypuklać szlachetność, mądrość i bezinteresowny altruizm tego ostatniego, co być przestrogą przed współczesnymi sofistami, którymi okazują się dla autorki postmoderniści. Niemalże od pierwszej do ostatniej strony straszy nas nimi, dodając do nich czasem liberałów. Już w Przedmowie czytamy: „Współcześnie człowiek znów staje się miarą wszystkiego w kierunkach zorientowanych antypedagogicznie. Nasuwa się tym samym myśl, że historia wychowania zatoczyła koło i dziś mamy ponownie do czynienia z próbami wywyższenia człowieka, jak to ma miejsce we współczesnym pajdocentryzmie czy pedagogikach budujących swoje koncepcje na postmodernistycznej antropologii. Warto zapytać, czy przełom neoliberalny zapoczątkowany w latach osiemdziesiątych XX wieku to nie "produkt" takiego właśnie myślenia o człowieku, uruchamiającego neoliberalną machinę miażdżącą umysły uczniów, nauczycieli, minimalizującą ich aktywność wychowawczą i samowychowawczą" (s. 11-12). Jeżeli ktoś ma chociażby elementarne (powiedzmy na poziomie szkoły średniej) wyobrażenie, jakie są założenia neoliberalizmu, ten czytając takie słowa, musi zadać sobie pytanie, o co właściwie autorce chodzi? Przecież 
zasady neoliberalizmu (odnoszące się przede wszystkim do sfery gospodarczej) promowały jednostkę aktywną, podejmującą działania. Może autorka jest zdania, że neoliberalizm to jakaś odmiana (mutacja?) totalitaryzmu? Wystarczy przypomnieć film Andrzeja Fidyka Defilada z końca lat 80. XX w., by uzmysłowić sobie, na czym polega prawdziwe „miażdżenie umysłów” uczniów i nauczycieli. A już szczytem dyletantyzmu jest kilkakrotne afirmatywne przywoływanie w tekście Augusta von Hayeka. Czyżby autorka nie zdawała sobie sprawy, że Hayek to jeden z czołowych przedstawicieli doktryny neoliberalnej? To samo dotyczy przywołanego wyżej pajdocentryzmu. Skoro autorka ma do niego aż tak krytyczny stosunek, to dlaczego z taką estymą pisze o czołowej przedstawicielce tego nurtu, Marii Montessorii? (s. 154-155).

Jodłowska w ogóle stara się „unaukowić” swoje wywody, sięgając po nazwiska z najwyższej intelektualnej półki. Cytuje np. Kanta, Hegla, Kierkegaarda, Schopenhauera, Nietzschego, Husserla, Heideggera, Arendt i wielu innych. Z niektórymi ma ochotę nawet polemizować, np. z Kantem. Formułuje bowiem wątpliwość, czy w jego przypadku „kontynuowana jest sokratejska mądrość aksjologiczna”. Na szczęście rezygnuje z tego karkołomnego (dla siebie) zadania, gdyż - jak stwierdza: „nie miejsce, by rozwijać tu te interesujące zapewne problemy” (s. 235).

Autorka nie jest co prawda filozofką, do czego się przyznaje, ale poziom naiwności w przywoływaniu myśli filozoficznej jest czasem wręcz żenujący. Kiedy cytuje np. Nietzschego, czy Hegla, to czyni to tylko po to, aby literalnie i dosłownie sparafrazować ich słowa. Nie rozumie, co to jest kontekst. Nie rozumie, że heglowski czy nietzscheański Sokrates, to nie to samo, co Sokrates historyczny. Za przykład niech posłuży komentarz Jodłowskiej do zacytowanego przez nią fragmentu Zmierzchu bożyszcz Nietzschego. Filozof, przywołując fakt brzydoty fizycznej Sokratesa, czyni taką oto aluzję do słynnej sokratejskiej ironii: „Antropologowie badający kryminalistów mówią nam, że typowy zbrodniarz jest brzydki: monstrum in fronte, monstrum in animo. Ale zbrodniarz jest décadent? Czy Sokrates był typowym zbrodniarzem?” (s. 38). Komentarz Jodłowskiej do tych słów jest taki: „Charakter Sokratesa ukształtowała ogromna i trwająca całe życie praca nad sobą. I z pewnością nie zasłużył sobie na takie przewrotne insynuacje, gdyż jak być może nikt inny w tym czasie dotarł "aż do moralnego ładu-kosmosu wewnątrz duszy samej»" (s. 38). Trudno nawet komentować taką interpretację... Można autorce tylko miłosiernie polecić lekturę jakiegoś elementarnego podręcznika do filozofii.

Jodłowska w swoim „studium” wielokrotnie diagnozuje też polską szkołę (także na poziomie akademickim) i polskich nauczycieli. I nie ma o nich dobrego zdania. Zarówno szkoła, jak i pedagodzy - jej zdaniem - tkwią bowiem w schematyzmie, rutynie, dogmatyzmie i - co najgorsze - w sofistyczno-postmodernistycznym paradygmacie. Oddajmy raz jeszcze głos autorce: „Współczesne szkoły 
i uczelnie kształcące nauczycieli pełne są wrogości, przemocy, kłótni, agresji, sofistyki” (s. 207). Pożądanych przez nią „nauczycieli sokratyków” (do których, rzecz jasna, sama siebie zalicza) jest niewielu. Przeważają „nauczyciele dogmatycy”. Przesłanką do takiego wniosku jest analiza... jednego zapisu lekcji, który został przywołany w aneksie ${ }^{1}$. Pominę kwestię metodologii zastosowanych przez autorkę narzędzi analizy tej lekcji, odwołującej się do metod statystycznych (s. 195-200). Tym, co zdumiewa bowiem najbardziej, jest zgeneralizowany wniosek, jaki autorka na tej kruchej podstawie formułuje: „Wniosek podstawowy, jaki się nasuwa, jest taki, że współczesna szkoła zamyka umysły uczniów, nie pozwala im samodzielnie myśleć i dochodzić do wiedzy, upośledzając lub wręcz blokując wychowanie prawdziwe, jakim jest z pewnością sokratejska propozycja wychowania do mądrości. Tym samym nauczyciel jakby nie wypełnia podstawowych zadań, do jakich jest zatrudniony w szkole" (s. 200). Można by w tym miejscu zapytać autorkę, czy jest to wniosek wyciągnięty metodą sokratyczną? Wynikający z majeutyki?

Takich pytań zresztą można by autorce postawić dużo więcej. Na przykład w jaki sposób doszła do wniosku, że „z pewnością jesteśmy świadkami formowania się światowego ładu moralnego jednoczącej się ludzkości”? (s. 239). Albo, na jakiej podstawie sformułowała zdanie, że żyjemy „w sytuacji jednoczenia się kultur europejskich”? (s. 254). Ciekawe, jak według Jodłowskiej będzie wyglądała ta „zjednoczona kultura europejska"?

Ciekawi mnie też, jakie autorka przeprowadziła badania, które upoważniają ją do stwierdzenia, że pedagogika sokratejska ma tak cudowną moc, że - jak to ujmuje - „milkną wówczas także problemy z uczniami trudnymi” (s. 118)². Pytanie tym bardziej wydaje się zasadne, że w innym miejscu Jodłowska stwierdza, że „uczniami Sokratesa byli Charmides i Krytiasz - postacie splamione w późniejszym okresie życia okrucieństwem i krwią wielu Ateńczyków” (s. 247). Zatem skoro nawet Sokrates odnotował porażkę pedagogiczną, to w jaki sposób mogą się jej ustrzec współcześni „nauczyciele sokratycy”? Na te i na wiele innych pytań nie ma jednak w książce odpowiedzi.

1 Autorka, co prawda, zastrzega, że badała wiele innych dialogów szkolnych, ale nie wskazuje tych badań, a jedynie powołuje się na swoją starą pracę z 1988 roku pt. „Start zawodowy nauczyciela klas początkowych”. Przywołana w aneksie lekcja miała natomiast miejsce w styczniu 2003 r.

2 Autorka jako podstawę takiego wniosku wskazuje „kilku studentów, którzy zajęcia z pedagogiki rozpoczęli manifestacją swojego negatywizmu, przeradzającego się w niedługim czasie w gotowość do uwagi, a później owocującego zainteresowaniem i pomocą w ich prowadzeniu, a wreszcie podjęciem pracy licencjackiej [pod kierunkiem autorki] i napisaniem artykułu naukowego, który został opublikowany w pracy naukowej" (s. 118). 
Nie będę dalej pastwił się nad autorką, której praca obnażyła braki na każdym polu kompetencji. Przyznam, że już dawno nie czytałem tak złej książki. Mam nawet wątpliwości, czy recenzentka, która wydała (jak mniemam) pozytywną o niej opinię, w rzeczywistości czytała ten tekst. Czyż można było bowiem nie zauważyć, że autorka te same partie tekstu przywołuje po kilka razy w różnych miejscach książki (takie powtórzenia znajdziemy np. na s. 94 i 99 [przypis nr 37]; na s. 34 i 100, na s. 136 i 191 etc.)? Czy można było przeoczyć, że praca jest niespójna i źle skonstruowana? Czy jest możliwe, aby po przeczytaniu tekstu, nie zauważyć aż tylu w nim sprzeczności?

Kończąc, raz jeszcze zacytuję autorkę recenzowanej publikacji. Pod koniec swoich rozważań Jodłowska stwierdza: „Dzisiejsza pedagogika jest nijaka. Ciągle niewiele liczy się wśród innych nauk. Ma niewielki dorobek teoretyczny. I nie jest to bolączka polskiej pedagogiki. Dlaczego tak jest?” (s. 245). No właśnie: dlaczego?

Mariusz Menz (Poznań)

\section{Próba adaptacji idei regionalistycznej do edukacji szkolnej. Recenzja publikacji Danuty Konieczka-Śliwińskiej pt: Edukacyjny nurt regionalizmu w Polsce po 1918 roku. Konteksty - koncepcje progra- mowe - realia, Wydawnictwo Instytutu Historii UAM, Poznań 2011, ss. 502}

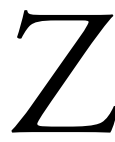

asadniczym warunkiem realizacji edukacji regionalnej jest świadomość społeczeństwa, a zwłaszcza władz oświatowych i nauczycieli. Istnieje potrzeba prowadzenia takiej edukacji, wobec postępujących procesów globalizacji, uniwersalizacji, co wiąże się także z unifikacją w dziedzinie oświaty i kultury. Tu szczególnie ważne staje się zachowanie tożsamości narodowej, a ta jest związana z ojczyzną najpierw prywatną, potem regionalną, dalej ogólnonarodową, a wreszcie ogólnoludzką. Odwoływanie się w procesie edukacji do wspólnoty miejsca urodzenia, tradycji daje szansę zachowania ciąłości ogólnonarodowej, a także europejskiej wspólnoty, której jesteśmy członkami.

W tym kontekście zagadnienia związane z regionem mieszczą się w kręgu zainteresowań badaczy wielu dziedzin nauki, ale też różnych instytucji i organizacji. 